\title{
Cocconeis Ehrenberg taxa (Bacillariophyta) with a marginal row of simple processes: relationship with the valvocopula system and distinctive features of related taxa
}

\author{
Catherine Riaux-Gobin ${ }^{* 1,2}$, Andrzej Witkowski ${ }^{3}$, Pierre Compère ${ }^{4} \&$ Oscar E. \\ ROMERO 5
}

${ }^{*}$ CRIOBE-USR 3278 CNRS-EPHE-UPVD, ${ }^{2}$ Laboratoire d'Excellence 'CORAIL',

F-66000 Perpignan, France; *Corresponding author e-mail: catherine.gobin@univ-perp.fr,

${ }^{3}$ University of Szczecin, The Faculty of Geosciences, Palaeoceanology Unit, PL-70-383 Szczecin, Poland; e-mail: witkowsk@univ.szczecin.pl

${ }_{4}^{4}$ Botanic Garden Meise, Domein van Bouchout, B-1860 Meise, Belgium; e-mail: pierre.compere@br.fgov.be

${ }^{5}$ MARUM, Center for Marine Environmental Sciences, University of Bremen, D-28359 Bremen, Germany; e-mail: oromero@uni-bremen.de

\begin{abstract}
As first observed on a group of taxa related to Cocconeis peltoides Hustedt, several other Cocconeis EHRENBERG (Bacillariophyta) taxa possess a row of minute marginal pores on the external side of their sternum valve (SV) connected to small and simple internal portules, or processes. These processes are often located in continuity with the striae, but can also be slightly shifted or distant from the distal areola of the striae. The row of pores is often, but not always, externally separated from the stria by a crista marginalis. Within Cocconeis, and possibly all raphid diatoms, these processes seem unique and restricted to a few taxa. A list is presented of the taxa pertaining (or close) to Cocconeis that are actually known to share these micro-structures. In addition, the morphological variability of the processes is described in detail and a morphological comparison of the taxa is provided. The characteristic features of taxa showing a row of SV processes permit the tentative definition of several morphological groups. It is difficult to prove the taxonomic affiliation of these taxa and demonstrate or refute that these processes are ancestral characters. Some of these taxa are rare and restricted to low latitudes (e.g., tropical taxa) while others are frequent and ubiquitous.
\end{abstract}

Key words: Achnanthales, Cocconeis, marginal processes, taxonomy, morphology

Abbreviations: (LM) light microscope, (SEM) scanning electron microscope, (RV) raphe valve, (SV) sternum valve, (RVVC) raphe valve valvocopula, (SVVC) sternum valve valvocopula

\section{INTRODUCTION}

Several genera of the Bacillariophyta show portules on their frustule. After Ross \& Sims 1972 and Hasle 1972 (see Round et al. 1990), the portules are classified into two main categories, 1) the fultoportulae, complex structures only present in the Thalassiosirales and, 2) the rimoportulae, simpler structures, more commonly found, e.g., in centric and araphid diatoms. Among the raphid diatoms (Bacillariophyceae), rimoportulae are infrequent but can be observed in some taxa of Eunotia C.G. Ehrenberg, Actinella F.W. Lewis, Peronia A. DE BréBISSON and Amphorotia Williams et ReID but only at the poles of the frustules. The genus Eunophora W. Vyverman, K. Sabbe et D.G. Mann also posse- sses rimoportulae (VYVERMAN et al. 1998). Moreover, somewhat simple stigmata, generally present near the central raphe endings, are observed in Cymbella $\mathrm{C}$. AgArdh, Gomphocymbella O. Müller, sometimes in Gomphonema C.G. Ehrenberg, Didymosphenia M. Schmidt, Gomphoneis P.T. Cleve, Reimeria J.P. KoCiolek et E.F. Stoermer, Luticola D.G. Mann and Proschkinia N.I. KARAYEVA (Round et al. 1990). A simple stigma is also present in Fistulifera LANGE-BERTALOT with an external opening called 'fistule' (LANGE-BERTALOT 1997), in Labellicula VAN DE VIJVER et LANGEBertalot (VAn de ViJVer et al. 2005) with a simple internal macula and an external pore sometimes difficult to detect, and in Olifantiella RiauX-GoBin et ComPÈRE with a complex internal tubular structure known 
as a 'buciniportula' (RIAuX-GoBin \& COMPÈRE 2009). Except for the portules present in centric diatoms, the latter processes are solitary or grouped at one or both poles of the frustule, or near the central area, but are never present as a row of regularly spaced structures near the margin of one valve, as in the case of several Achnanthales assigned to the family Cocconeidaceae.

A marginal row of simple and regularly spaced processes was previously described for Cocconeis peltoides Hustedt, C. peltoides var. archaeana RiauX-Gobin et Compère, $C$. sigillata RiauX-Gobin et Al-Handal, C. hauniensis WitKowsKi emend. WITKowski, C. germainii Riaux-Gobin, Witkowski et RoMERo (RIAUX-Gobin et al. 2011a) and in C. pseudograta Hustedt (Romero \& Riaux-Gobin 2014). Several other taxa with such a row of processes were briefly mentioned in RiauX-Gobin \& Romero (2003) and RiauX-Gobin et al. (2011b). In the present paper we compile these taxa again, along with a new species and two additional rare, poorly documented and undefined taxa. We comment on the morphological variability of the processes and the possible relationship of these micro-structures to the sternum valve valvocopula (SVVC). The morphological origin and role of these processes still remain unclear. The characteristics in common with the studied taxa are discussed.

\section{Material and Methods}

Marine intertidal samples were collected between 2010 to 2013 from 1) the Austral Ocean (Kerguelen Islands, $49^{\circ} 20^{\prime} \mathrm{S}$, $69^{\circ} 20^{\prime} \mathrm{E}$ ) from 1985 to 1992,2 ) the Indian Ocean (Mascarene Archipelago, Reunion Island $21^{\circ} 6^{\prime} \mathrm{S}, 55^{\circ} 36^{\prime} \mathrm{E}$ and Rodrigues Island $19^{\circ} 43^{\prime} \mathrm{S}, 6^{\circ} 25^{\prime} \mathrm{E}$ ) from 2005 to 2009 , Scattered Islands (Eparses, e.g. Juan de Nova $17^{\circ} 02.797^{\prime} \mathrm{S}, 42^{\circ} 43.811^{\prime}$ E) in 2009 and Madagascar (Nosy Be, 13 ${ }^{\circ} 19^{\prime} \mathrm{S}, 48^{\circ} 19^{\prime} \mathrm{E}$ ) in 2014, and 3) the South Pacific (Society Archipelago, 17²32' S, $149^{\circ} 50^{\prime} \mathrm{W}$ and Tuamotu Archipelago, $18^{\circ} 02^{\prime} \mathrm{S}, 141^{\circ} 24^{\prime}$ $\mathrm{W})$. The samples (sediments, turf, macroalgae, tide marks, holothurian scrapes, mangrove root scrapes or coral debris) were examined with a scanning electron microscope (SEM) that can discriminate very small morphological details. The samples were preserved in formaldehyde (10\% final concentration), filtered through $1 \mu \mathrm{m}$ Nuclepore ${ }^{\circledR}$ filters $(13 \mathrm{~mm}$ in diam.) and rinsed twice with deionised (milli- $\mathrm{Q}^{\circledR}$ ) water to remove salts. Filters were air-dried and mounted in toto onto aluminum stubs before ion coating with gold-palladium alloy (EMSCOP SC 500 sputter coater) and examined with a Hitachi S-4500 SEM operated at $5 \mathrm{kV}$ (C2M, Perpignan University, France). The SEM was recently calibrated using a silicon calibration grating TGX01. Although it is a challenge to permanently preserve specimens on stubs, they are referenced and kept in an air-dried container at CRIOBE-Perpignan University, France.

The general terminology used for the diatom frustules follows Anonymous (1975) and Ross et al. (1979).

Table 1. List of discussed taxa showing a row of minute processes on their SV, distribution. Number refers to morphological group (see text); (K) Kerguelen Islands, (Rod) Rodrigues Island, (Reu) Reunion Island, (S) Scattered Islands, (Soc) Society Islands, (T) Tuamotu Islands, (NB) Nosy Be, Madagascar, (TEMP) Temperate Ubiquitous, (TROP) Tropical Ubiquitous.

\begin{tabular}{llll}
\hline Name & Figs 1-17 & group & distribution \\
\hline Cocconeis cupulifera & 14 & 2B & Rod \\
Cocconeis germainii & 5 & $1 \mathrm{~B}$ & $\mathrm{~K}$ \\
Cocconeis hauniensis & 15 & 2B & TEMP, K \\
Cocconeis inequalistriata & 13 & 2B & Reu, Rod \\
Cocconeis juandenovensis sp. nov. & 4 & $1 \mathrm{~A}$ & S \\
Cocconeis paucistriata & 7 & $1 \mathrm{C}$ & Rod, Soc \\
Cocconeis peltoides & 1 & $1 \mathrm{~A}$ & TEMP, TROP, T \\
Cocconeis peltoides var. archaeana & 2 & $1 \mathrm{~A}$ & TROP \\
Cocconeis pseudograta & 8 & $2 \mathrm{~A}$ & TEMP, TROP \\
Cocconeis sigillata & 3 & $1 \mathrm{~A}$ & TROP \\
Cocconeis sp. 1 & 6 & $1 \mathrm{~B}$ & K \\
Cocconeis sp. 2 & 11 & 3 & Rod \\
Cocconeis sp. 3 & 17 & 4 & Ker \\
Cocconeis sp. 4 & 12 & 3 & Rod, Reu, E, NB \\
(?)Cocconeis sp. 5 & 10 & $2 \mathrm{~A}$ & Rod \\
(?)Cocconeis sp. 6 & 16 & 4 & Rod, Soc \\
(?)Cocconeis sp. 7 & 9 & Soc \\
\hline
\end{tabular}




\section{RESUlTS}

Numerous Cocconeis taxa were described from the above cited campaigns (see e.g., Riaux-GoBin et al. 2007, 2009, 2011a,b) and the observation conducted with the SEM at high resolution permitted the distinction of almost 17 taxa assumed to pertain to Cocconeis, or a closely related genus, that show a row of small pores on the margin of their SV (Figs 1-17, 18-39). The list and distribution of the discussed taxa are given in Table 1. From previous descriptions (op. cit., also RiauX-Gobin \& Romero 2003 and Romero \& RiauXGobIN 2014) and the present description of Cocconeis juadenovensis sp. nov., Cocconeis sp. 7 and ?Cocconeis sp. 6, along with new details concerning processes (see Taxonomic remarks), the most important features of the implied taxa are summarized in Table 2.

The SV external side of the 17 latter taxa (Figs $1-17,19,29,32-34,38)$ incontestably shows a row of marginal processes, and although several of these taxa are fully described, details of other taxa are incompletely known: i.e., they lack information on their RV and/ or the internal structure of the SV processes (Table 2). Furthermore, the internal structure of the processes seems polymorphic in some cases, e.g., concerning Cocconeis peltoides (see comments below). The RV, when known, has generally a denser striation than the $\mathrm{SV}$ and shows marginal shorter striae and/or a row of marginal macroareolae. Nevertheless the latter characteristics do not permit the definition of groups. Several taxa have a SV crista marginalis separating the row of processes from the valve face, but some specimens of e.g., Cocconeis sigillata show a more or less deep marginal groove while others show a real crista marginalis, without any specific repartition among these specimens (see Taxonomic remarks). So, here again, the presence of a crista marginalis does not permit the clear delinea- tion of the groups. On the other hand, the morphology of the SV striae and SV sternum of the 17 studied taxa (Figs 1-17), show characteristics permitting grouping to some extent.

Following the previous comments, four main groups of taxa are tentatively defined, showing a row of marginal SV processes, taking into account their SV stria pattern and SV sternum width and ornamentation (see Table 1 for the name of the taxa; numbers refer to Figs 1-17).

\section{Taxonomic Remarks}

See the cited references for full description and illustration of each taxon. Some additional taxonomic remarks and SEM illustrations are added (see below).

\section{Group 1 SV striae split into two distinct sectors} Sub-group $1 A$ 'peltoides group' sternum narrow and concave, hemi-valves strongly convex with two raised furrows splitting the striae or with raised and convex irregular virgae with axial projections

\section{Cocconeis peltoides Hustedt (Figs 1, 19-21, 39)}

(Hustedt 1939, 606-607, figs 23-27). Illustrated in SundBäck \& SNOEIS (1991, fig. 9a-c); SAR et al. (2003, figs 34-38); RiAUX-GobiN et al. (2011a, figs 1-22); RiauX-Gobin et al. (2011b, pls 58-59); MAJEWSKA et al. (2014, fig. 18). Possibly illustrated as Cocconeis disculus (Schumann) Cleve in Montgomery 1978 (pl. 60, D).

Features (Mascarene specimens, RiauX-Gobin et al. 2011b) SEM: 8.5-22 (12.5 + 3.3) $\mu \mathrm{m}$ long; 5.4-15.4 $(7.6 \pm 2.3) \mu \mathrm{m}$ wide; SV 12.2-16.3 (13.2 \pm 1.3$)$ str. in $10 \mu \mathrm{m} ; 18-20$ areolae in $10 \mu \mathrm{m}$. RV 41.5-56.9 (50.5 $\pm 6)$ str. in $10 \mu \mathrm{m}, 49-73$ areolae in $10 \mu \mathrm{m}$. The South Pacific and Scattered Islands specimens have morphometrics close to those from Mascarenes.

Remarks on SV processes and RV: Taxon highly po-

Group 1) SV striae split into two distinct parts (-sectors):

1A) sternum narrow and concave, hemi-valves (area from the sternum to the margin) strongly convex with two raised furrows splitting the striae $\ldots \ldots \ldots \ldots \ldots \ldots \ldots \ldots \ldots \ldots \ldots \ldots \ldots \ldots \ldots \ldots$ or with raised and convex irregular virgae with axial projections $\ldots \ldots \ldots \ldots \ldots \ldots \ldots$ 1B) mid-valve flat with ornamentation and areolae loosely arranged, two hyaline low furrows splitting the two parts of the striae, central area void of areolae $\ldots \ldots \ldots \ldots \ldots \ldots \ldots \ldots \ldots$

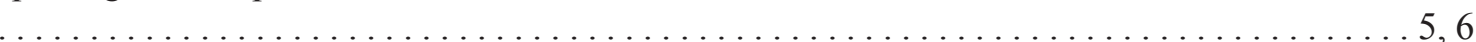

1C) striae composed of very few areolae $\ldots \ldots \ldots \ldots \ldots \ldots \ldots \ldots \ldots \ldots \ldots \ldots \ldots \ldots$

Group 2) SV striae composed of numerous areolae, with no partition, large sternum void of areolae:

2A) ornamentation on the sternum or on all the valve face (nodules and/or raised virgae) .......

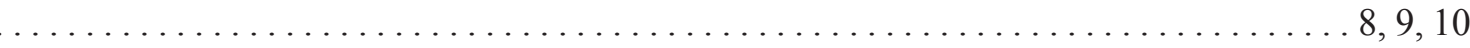
2B) ornamentation exclusively on the sternum (cupules, vestigial raphe, low structures at the end

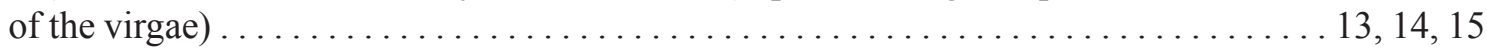

Group 3) SV striae very short, marginal and regular (composed of a few minute areolae), raised and radiate structures on the sternum and on the virgae, giving the appearance of a partition of the striae.

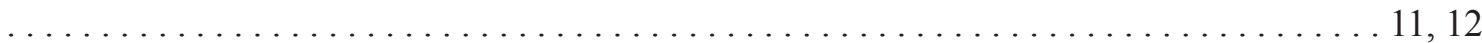

Group 4) SV striae composed of coarse areolae, without partition, RV unknown . . . . . . . . . 16, 17 


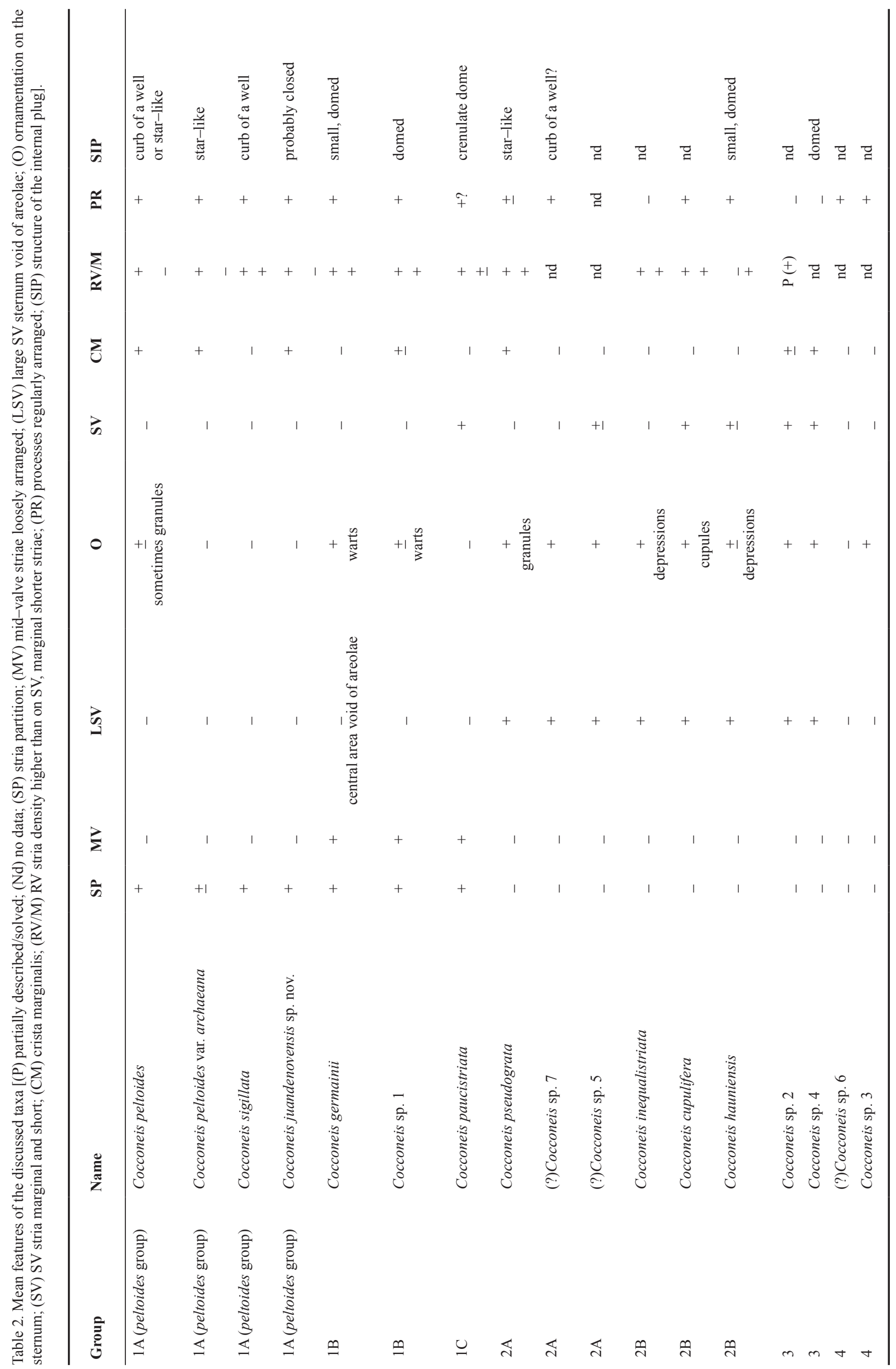


lymorphic. The RV has a marginal row of macroareolae in continuity with the striae (no marginal shorter striae). The processes locate on the mantle, often on the edge of the rim (Fig. 19) and not on the bottom of the groove delimited by the crista marginalis and cingulum. In some specimens, each process externally opens on the top of a protuberance (Fig. 19), but can also be simple (not illustrated). The internal process may be like a curb of a well, apparently open (Fig. 20), but is also observed as closed by a helicoidal star-like plug (Fig. 21).

Distribution: Ubiquitous taxon.

Cocconeis peltoides var. archaeana RIAUX-GoBIN et COMPÈre (Fig. 2)

(Riaux-Gobin et al. 2011a, figs 23-34; as Cocconeis archaeana RIAUX-GobIN \& COMPère in RIAUX-Gobin et al. 2011b-nom. inval.-, pl. 30/figs 1-6). Possibly illustrated in Montgomery (1978, pl. 62, A, as Cocconeis sp. 7).

Features (Mascarene specimens, RiauX-Gobin et al. 2011b) SEM: $\mathrm{n}=30 ; 8-10.6(9.2 \pm 0.8) \mu \mathrm{m}$ long; 4.5-7 $(5.5 \pm 0.7) \mu \mathrm{m}$ wide; SV 12-17.6 (14.4 \pm 1.6$)$ str. in $10 \mu \mathrm{m} ; 24-33$ areolae in $10 \mu \mathrm{m}$. RV 46.3-57 (53.3 \pm 3.5) str. in $10 \mu \mathrm{m}, 65-70$ areolae in $10 \mu \mathrm{m}$. The South Pacific specimens have morphometrics close to those from Mascarenes.

Remarks on SV processes and RV: The SV processes are present in each row of striae and are internally closed by a star-like plug (RIAUX-GoBIN et al. 2011, pl. 30, fig. 5, white arrow), they open externally as a row of pores on the bottom of the groove delineated by the crista marginalis and the edge of the mantle. The external pores are often coarse with raised edges (RIAUXGoBIN et al. 2011b, pl. 30, fig. 3, arrow). RV similar to that of $C$. peltoides.

Distribution: Rare in the South Pacific, up to now not found in the Scattered Islands.

\section{Cocconeis sigillata Riaux-Gobin et AL-Handal (Fig. 3 ) \\ (RIAUX-GoBin et al. 2011a, figs 35-45).}

Features (Mascarene specimens, RiaUX-Gobin et al. 2011b) SEM: 7-10 $\mu \mathrm{m}$ long; 5-6 $\mu \mathrm{m}$ wide; SV 14.520 str. in $10 \mu \mathrm{m} ; 49-53$ areolae in quincunx in $10 \mu \mathrm{m}$. RV 57-65 str. in $10 \mu \mathrm{m}, 65-81$ areolae in $10 \mu \mathrm{m}$.

Remarks on SV processes and RV: Taxon highly polymorphic. Some rare and large specimens from Rodrigues possess a crista marginalis, while others lack the elevated axial crest splitting the striae into two parts. The processes, one for each SV stria, open externally in a marginal groove. The processes are apparently internally open, with the structure of a curb of a well (RIAuX-Gobin et al. 2011b, pl. 69, fig. 3, arrow). Taxon found in Indian Ocean (abundant in Reunion and also in Rodrigues, up to now not found in the Scattered Islands), also present in the South Pacific (Moorea, Tahiti Islands) with comparable features.
Distribution: This taxon is an ubiquitous tropical form.

Cocconeis juandenovensis RIAUX-GoBIN et WITKOWSKI sp. nov. (Figs 4, 24-29)

Features (Juan de Nova specimens) SEM. n=14; 10.8 $12.9(12.44 \pm 1.6) \mu \mathrm{m}$ long; 6.3-7.9 (7.3 \pm 0.4$) \mu \mathrm{m}$ wide; SV 16.4-20.5 (18.3 \pm 1.2$)$ str. in $10 \mu \mathrm{m} ; 40-43$ SV areolae in $10 \mu \mathrm{m}$. RV 53-66 marginal str. in $10 \mu \mathrm{m}$. Description: This taxon has a constant and regular ornamentation with a strong partition of the SV striae and a regular crista marginalis (Fig. 27). On the middle axial part, the short striae have exactly the same pattern as those in the lateral sectors, e.g., with same areola density and elevated virgae. The SV sternum is narrow, with no ornamentation. The SV striae are uniseriate and radiate. The SVVC has short regular fimbriae (Fig. 27). Processes are present in each stria, on the margin of the SV, opening as a tiny pore at the border of the groove, on the mantle (Fig. 29). In internal view, the processes are much smaller than the areolae (Fig. 25, arrows), they are probably closed, but on the three internal views observed the areolae and processes were eroded. Two RV external views (Figs 26, 28), assumed to pertain to this taxon, have been observed in the same sample '16502', with a great similitude with the RV of Cocconeis peltoides, but with higher stria density.

Holotype: SEM stub referenced '3 19/02/2014' in collection C. Riaux-Gobin, USR 3278, Perpignan, France, illustrated by the SEM Fig. 27, '280214-12'.

Isotypes: Slide BM 101783 (National History Museum, U.K-London), slide '16502' (collection A. Witkowski, Faculty of Geosciences, Szczecin, Poland) and slide 'JDN 3' (collection C. Riaux-Gobin, USR 3278, Perpignan, France).

Type locality: Sample '16502', Juan de Nova (17 02.797'“'S; 42 43.811' E). April 2009.

Etymology: The epithet juandenovensis refers to the Juan de Nova Island (Scattered Islands, Mozambique Channel) from where the taxon was discovered.

Remarks: This taxon is larger than the Cocconeis peltoides specimens currently observed in tropical environments (see above) and has SV stria and areola densities that are much higher and much more regular. Cocconeis juandenovensis has some affinity with the Rhaphoneis-like taxa illustrated in SCHMIDT et al. (1874-1959, pl. 191, figs 13, 14), but with a narrower SV axial area. Also some affinity with C. Aluminensis (Grunow) Peragallo (see Hustedt 1933, fig. 794, on left hand side), but with a middle field strongly punctuated and well organized as on the lateral sectors. The taxon illustrated from Rodrigues Island, as ' $\mathrm{Co}$ cconeis peltoides morphotype Rodrigues' (in RIAUXGobIN et al. 2011b, pl. 60, figs 1-3) may be close to C. juandenovensis but with SV striae and areolae less dense.

Distribution: Juan de Nova Island. 


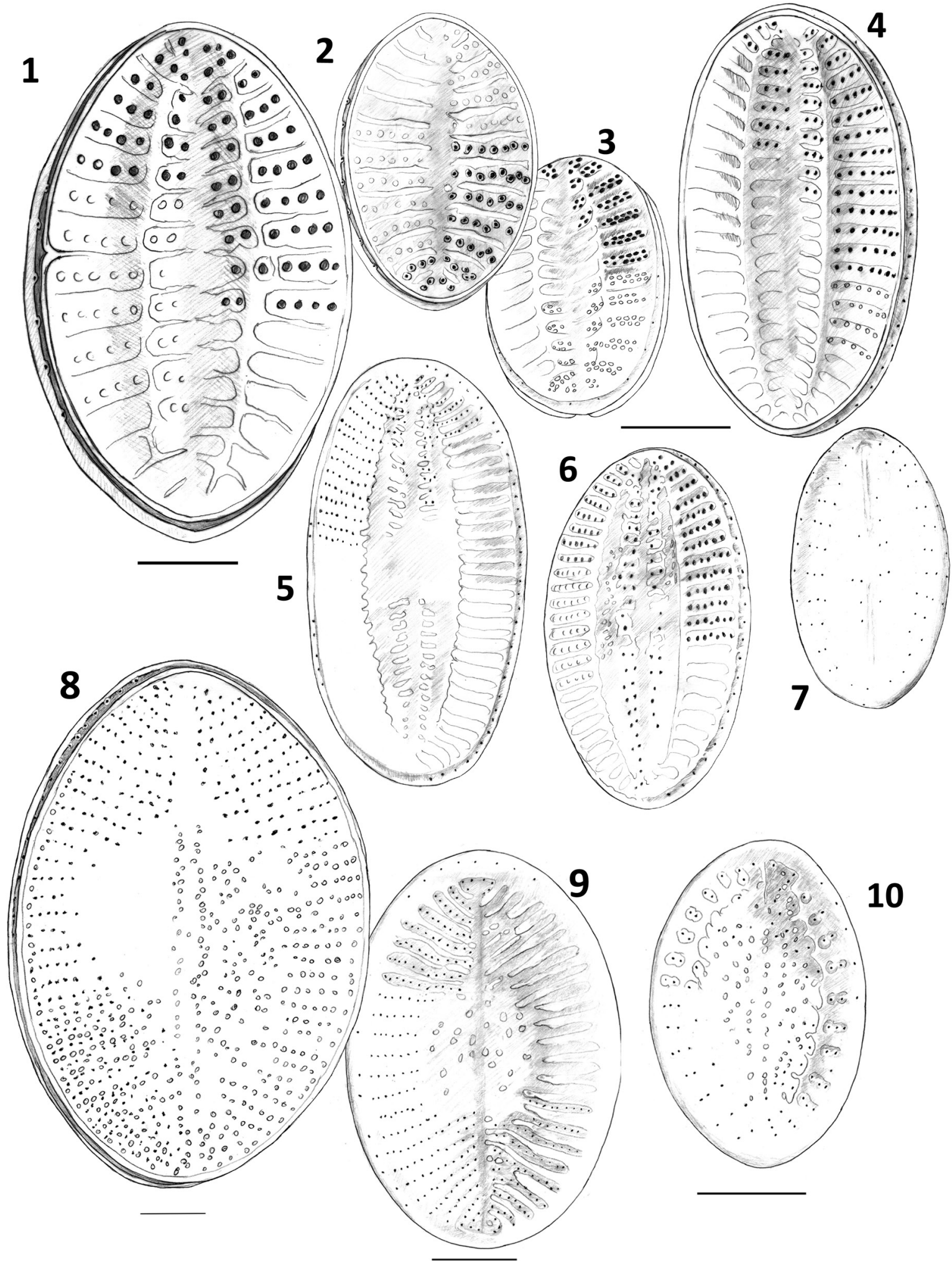

Figs 1-10. (1) Cocconeis peltoides; (2) C. peltoides var. archaeana; (3) C. sigillata; (4) C. juandenovensis sp. nov.; (5) C. germainii; (6) C. sp. 1; (7) C. paucistriata; (8) C. pseudograta; (9) C. sp. 7; (10) ?C.sp. 5. Scale bars $3 \mu \mathrm{m}$ (scale bar at the top on right hand, for Figs 2-7). 


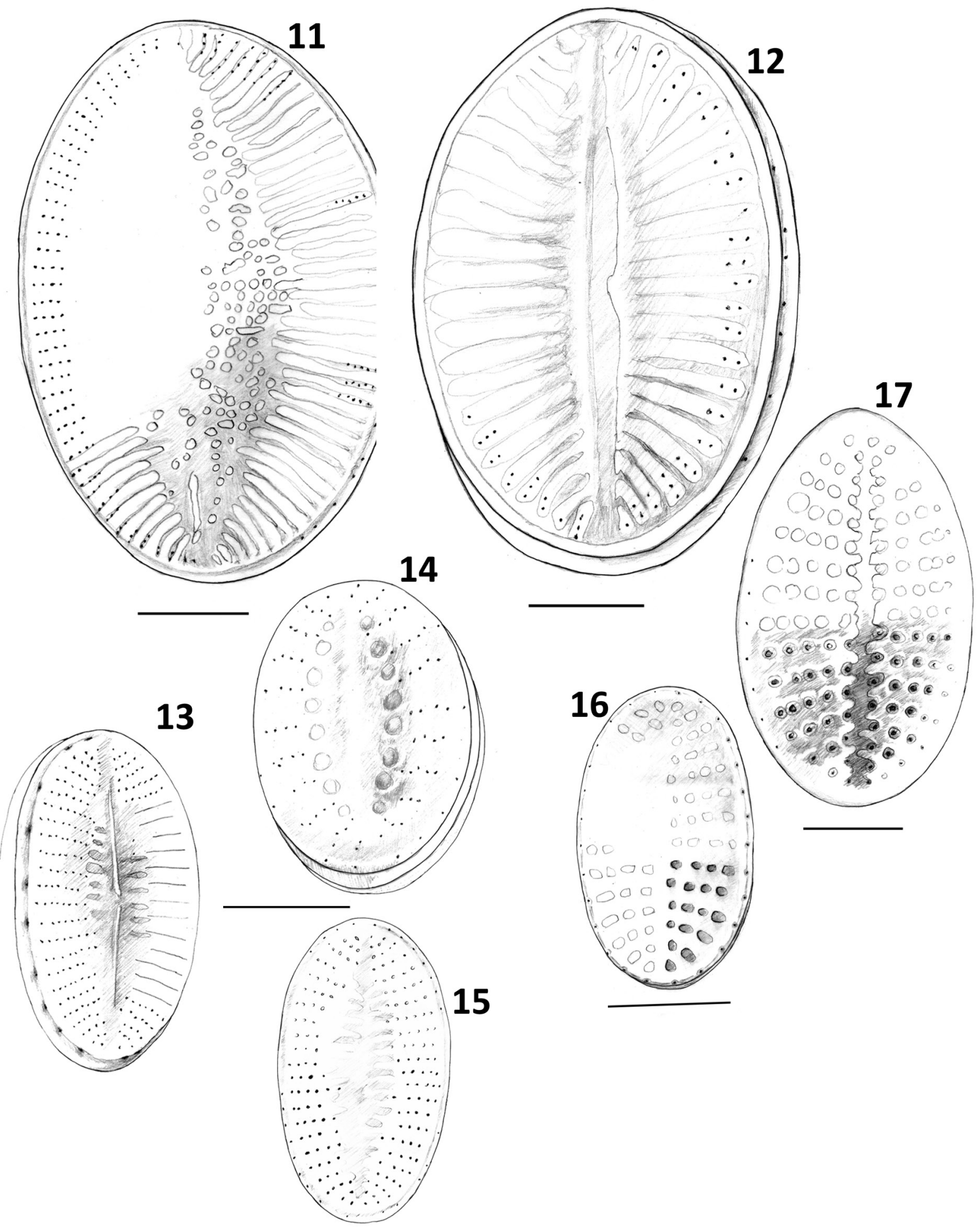

Figs 11-17. (11) C. sp. 2; (12) C. sp. 4; (13) C. inequalistriata; (14) C. cupulifera; (15) C. hauniensis; (16) ?C. sp. 6; (17) C. sp. 3. Scale bars $3 \mu \mathrm{m}$ (scale bar at the bottom on left hand, for Figs 13-15). 


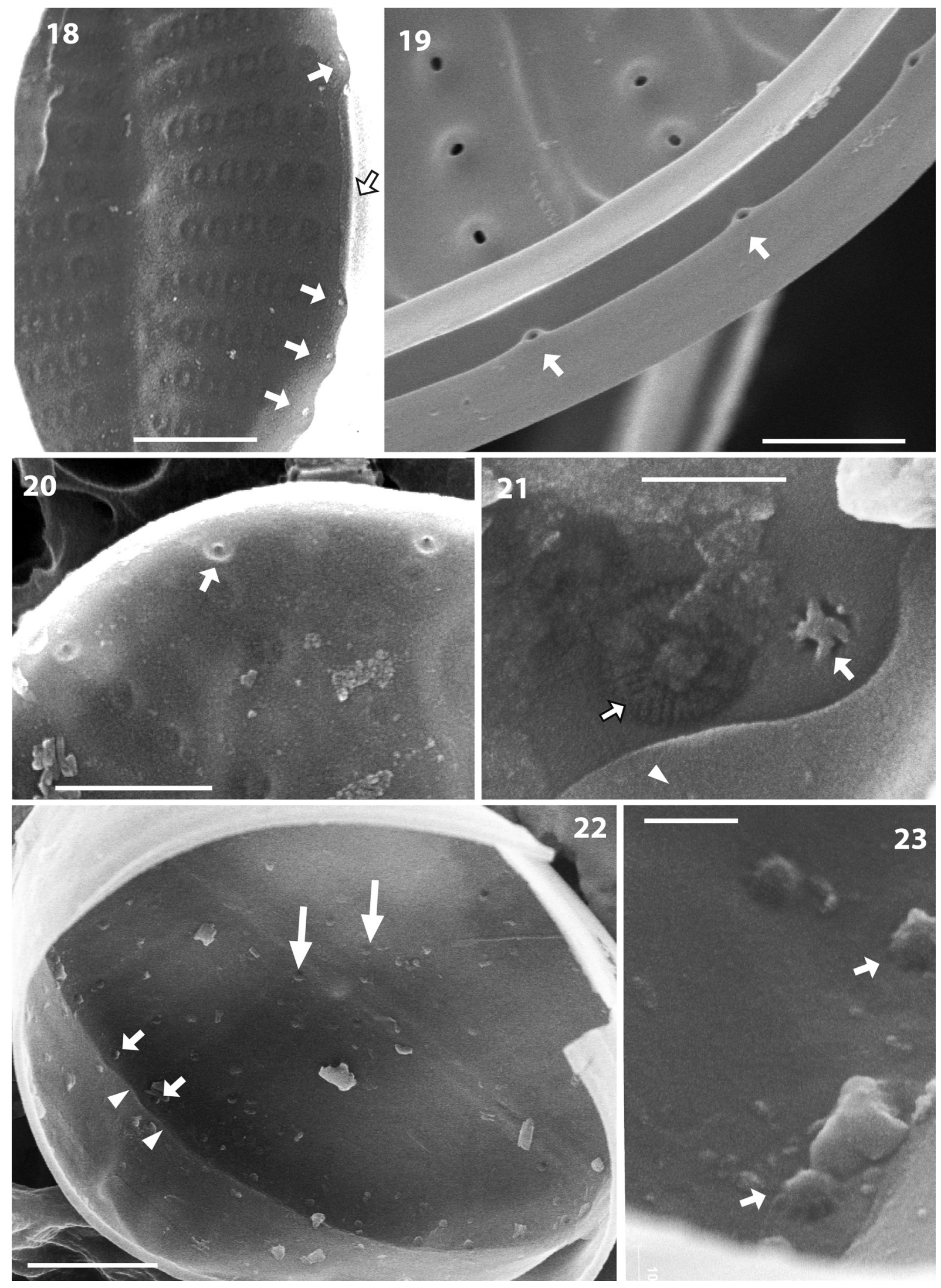



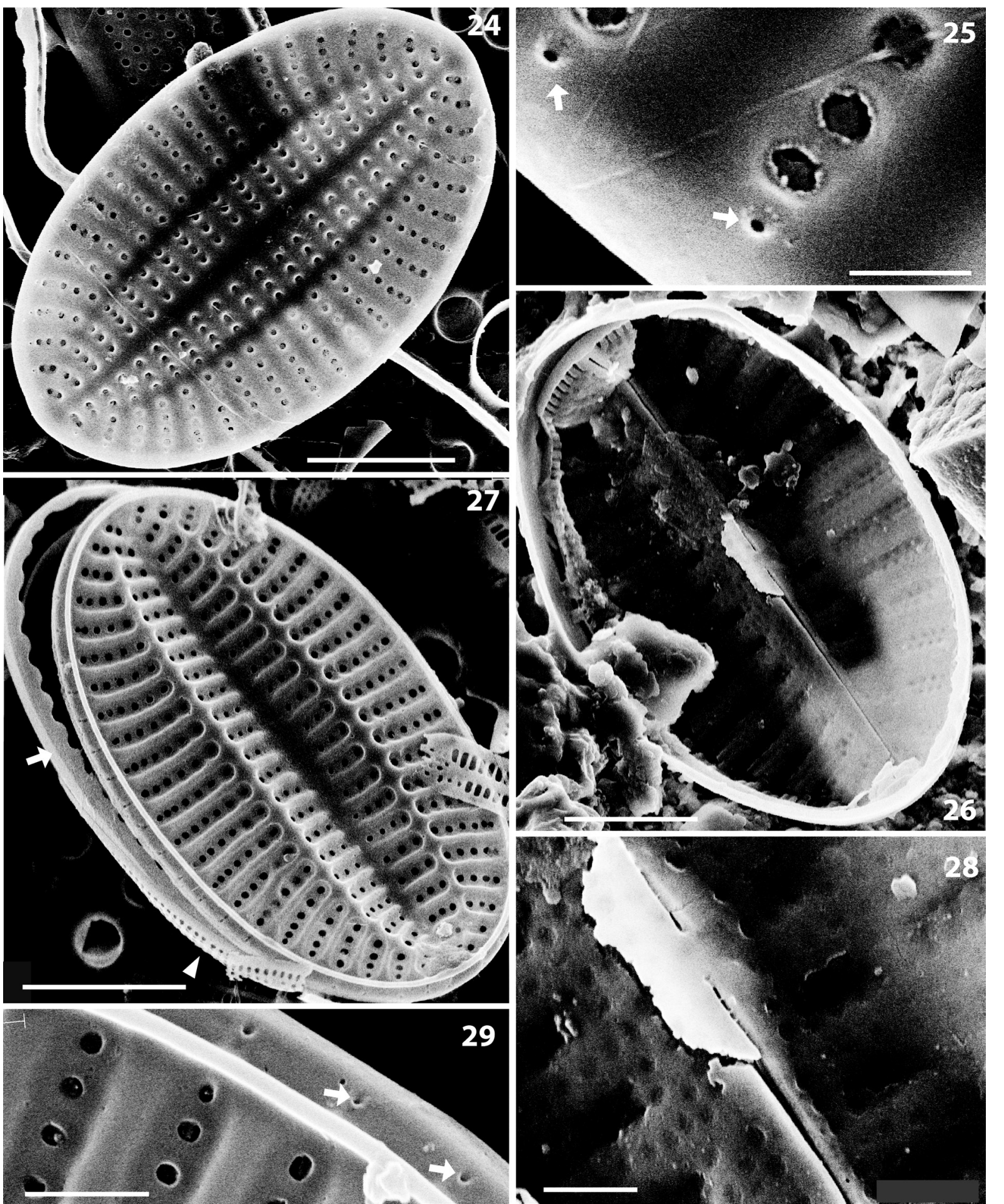

Figs 24-29. Cocconeis juandenovensis sp. nov., SEM: (24-25) SV internal views, with processes (eroded, arrows); (27) SV external view, with the SVVC (arrow) and the RV margin (arrow-head); (29) crista marginalis and process openings (arrows); $(26,28)$ RV in external view, with detail of the central area. Scale bars $3 \mu \mathrm{m}$ (Figs 24, 27); $2 \mu \mathrm{m}$ (Fig. 26); $0.6 \mu \mathrm{m}$ (Fig. 29); $0.5 \mu \mathrm{m}$ (Fig. 28); $0.3 \mu \mathrm{m}$ (Fig. 25).

Figs 18-23. (SEM): (18) C. hauniensis, SV internal view of Cocconeis hauniensis, with small domed processes (white arrows) and SVVC showing low fimbriae in between each process, and a zone without fimbriae (framed arrow); (19-21) C. peltoides, (19) SV external view of $C$. peltoides, with the process pores lying on the rim of the groove (arrows), (20) (from Bibliotheca Diatomologica 57, pl. 58/fig. 3, with permission, www.schweizerbart.de): SV internal view of C. peltoides showing processes with a curb of a well structure (arrow), (21) SV internal view of $C$. peltoides showing a process with a star-like structure (arrow), the areola hymenes with radial slits (framed arrow) and the SVVC fimbriae (arrow-head); (22, 23) C. paucistriata, (22) SV internal view of C. paucistriata with small domed areola hymemes (long arrows), processes (short arrows) and undulations-low fimbriae of the SVVC (arrow-heads). Note the vestigial raphe, (23) detail of Fig. 22, showing the structure of the crenulate processes (arrows). Scale bars $1 \mu \mathrm{m}$ (Figs 18, 22); 0.8 (Fig. 20); $0.7 \mu \mathrm{m}$ (Fig. 19); 0.2 (Fig. 21); 0.1 (Fig. 23). 
Sub-group 1B mid-valve flat with ornamentation and areolae loosely arranged, two hyaline low furrows splitting the two parts of the striae, central area void of areolae

Cocconeis germainii RIAUX-GobIN, WITKOWSKI et RoMero (Fig. 5)

(RiauX-Gobin et al. 2007, figs 7-9, LM; pls 2, 3, SEM; RiauX-Gobin et al. 2011a), previously presented as Cocconeis sp. [aff. C. fluminensis var. subimpleta Peragallo] in RiauX-Gobin \& Romero (2003, pl. 38 , figs 4 , 6; pl. 39, fig. 2).

Features (Kerguelen specimens, in RiaUX-GoBIN et al. 2011a) SEM: 11-15.2 $\mu \mathrm{m}$ long; 5.8-8.5 $\mu \mathrm{m}$ wide; SV 19.6-23.5 str. in $10 \mu \mathrm{m}$; 43.5-52.2 areolae in $10 \mu \mathrm{m}$; RV 43.5-56.5; 34.8-43.5 areolae in $10 \mu \mathrm{m}$.

Remarks on SV processes and RV: The SV processes are present in each stria and are located on a groove and are internally closed by small domed structures slightly bigger than the areolae (RIAUX-Gobin \& Romero 2003, pl. 39, fig. 2, on left hand side; RiauX-Gobin et al. 2007, pl. 2, fig. 4, white arrow). The RV has denser striae near the margin.

Distribution: Kerguelen.

\section{Cocconeis sp. 1 (Fig. 6)}

Some affinities with Cocconeis aff. fluminensis var. ? subimpleta Peragallo (Peragallo \& Peragallo 1897-1908; pl. 3, fig. 13), previously presented as Cocconeis sp. [aff. C. peltoides HustedT] in RiauX-Gobin \& Romero (2003, pl. 40, figs 1-9, 6, 7; (?)pl. 39, figs 5, 7; figs 67, 68).

Features (Kerguelen specimens) SEM: $\mathrm{n}=7$ : $\min .-$ max. 8.5-19.7 (mean 11.2 \pm standard deviation $\sigma$ 3.9) $\mu \mathrm{m}$ long; $6-11.2(6.7 \pm 2.1) \mu \mathrm{m}$ wide; $\mathrm{L} / \mathrm{W}: 1.42-2$ $(1.65 \pm 0.21) ; \mathrm{SV} 16-24.6(21.1 \pm 2.8) \mathrm{str}$. in $10 \mu \mathrm{m}$; $35-50$ areolae in $10 \mu \mathrm{m}$. (?)RV $24-26$ str. in $10 \mu \mathrm{m}$, 36-46 areolae in $10 \mu \mathrm{m}$.

Remarks on SV processes and RV: The RV is very similar to that of $C$. germainii (see below), with marginal intercalary striae, except for a lower striation. The SV processes open externally by small pores opening in a low groove. Internally, the processes are domed and located between each SVVC fimbria (RIAUX-GoBIN et al. 2007, pl. 40, fig. 8, arrow). A bigger specimen illustrated in RiauX-Gobin \& Romero (2003, pl. 40, fig. 10) shows some similarity with $C$. sovereignii HustedT (1955, p. 16, 5. 6-7) but with a more elongate frustule shape and higher stria density.

Distribution: Rare taxon from Kerguelen.

\section{Sub-group 1C striae composed of very few areolae}

Cocconeis paucistriata RIAUX-GobIN et al. (Figs 7, 22, 23)

(RiauX-Gobin et al. 2011b, p. 31, pl. 57, figs 1-7).

Features (Rodrigues and Tahiti Islands specimens) SEM: $n=9,5.8-18.8(7.2 \pm 1) \mu \mathrm{m}$ long; 3.6-4.8 (4.3 \pm
$0.4) \mu \mathrm{m}$ wide; SV 15-22 (18.2 \pm 2.7$)$ str. in $10 \mu \mathrm{m}$; RV 54 (59.2 on the margin) str. in $10 \mu \mathrm{m}$.

Remarks on SV processes and RV: The pores are well apart from the marginal striae, are present in each stria and are not located in a groove. In internal view the processes are plugged by an elevated crenulated plug, slightly bigger and higher than the areolae (Fig. 23, arrows). The SVVC has low fimbriae-undulations (Fig 22, arrowheads). Two specimens found in Tahiti Island are similar to those from Rodrigues Island.

Distribution: Rodrigues and Tahiti Islands.

Group 2 SV striae composed of numerous areolae, with no partition, large sternum void of areolae $2 A$ ornamentation on the sternum or on all the valve face (nodules and-or raised virgae

\section{Cocconeis pseudograta Hustedt 1939 (Fig. 8)}

(as Cocconeis grata A.SснмidT sensu Hustedt 1933, fig. 795). Illustration of the neotype slide Zt4/62 by SimONSEN 1987, pl. 375, figs 9-14. Illustrated in ROMERo \& RiauX-Gobin (2014); as Cocconeis cf. pseudograta in RiauX-GoBin et al. (2011b, pls 64, 65).

Features (Mascarene specimens, as Cocconeis cf. pseudograta in RIAUX-GoBIN et al. 2011b) SEM: 1423 (18.6 \pm 3.7) $\mu \mathrm{m}$ long; 9-18 (11.4 \pm 4.8) $\mu \mathrm{m}$ wide; SV 13-26 (18.3 \pm 3.9$)$ str. in $10 \mu \mathrm{m}$; RV 23-37 in 10 $\mu \mathrm{m}$, adjacent to the axial area $(28.8 \pm 5.8)$; 44-65 in margin $(49 \pm 8.4)$.

Remarks on SV processes and RV: The SV processes, more or less irregularly arranged (one per stria or around two per four SV striae) open externally on the rim of the groove delimited by the crista marginalis and the edge of the mantle (not shown) and are internally closed by a minute star-like plug (see illustration in Romero \& Riaux-Gobin 2014). The RV is polymorphic and shows marginal intercalary striae with oblong areolae, abrupt changes in stria orientation (not shown) and internally domed hymenes apparently in connection (not shown).

Distribution: This taxon is present at both ends of the Indo-Pacific Basin (Indian Ocean and South Pacific Ocean) with morphometrics close to those from Mascarenes.

Note: A forma is present in Juan de Nova Island (Scattered Islands) with morphometrics slightly different from those of Mascarenes and South Pacific, e.g., with a smaller size, a more discoid valve shape and granules lying in between each areola and not on the virgae. This probable variety will be detailed elsewhere.

(?)Cocconeis sp. 7 (Figs 9, 35-38)

Features (Tahiti Island specimens) SEM: $n=2 ; 9.8-$ $12.8 \mu \mathrm{m}$ long; $7.3-8.9 \mu \mathrm{m}$ wide; SV $18-20.6$ str. in 10 $\mu \mathrm{m} .41$ to 46 areolae in $10 \mathrm{~m}$. RV unknown.

Description: Small-celled taxon, elliptical with round apices (Fig. 35). SV striae radiate, shortened in mid- 
valve, slightly denser on apices, uninterrupted, composed of regularly spaced small areolae. Presence of a low sub-quadrangular central area void of areolae, ornamented with some warts. Raised irregular virgae on each marginal side of the valve (these structures are not longer than the striae). Wide hyaline margin with a row of tiny pores (one to each stria, Fig. 38). Internally the SV areolae and the processes seem opened with a ring of granules, possibly due to corrosion of the valve (Fig. 37). The areolae are arranged slightly in zig-zag. The processes are more regular in shape than the areolae, and open at the top of a small round dome (Fig. 37, arrowheads).

Remarks: RV unknown, so, its ascription to Cocconeis remains doubtful. Nevertheless the stria are reminiscent of that in Cocconeis pseudograta, but with raised virgae in place of nodules, and with no crista marginalis.

Distribution: The two specimens observed were found in a sample from Tahiti Island ('Papeete 4 holoth', holothurian scrape).

\section{(?)Cocconeis sp. 5 (Fig. 10)}

(as (?)Cocconeis sp.3 in RiaUX-Gobin et al. 2011b, p. 42, pl. 87, figs $1-4)$ is up to now undefined.

Features (Rodrigues Island specimens) SEM: $n=6$, 8.6-13.2 (11.3 \pm 2.4$) \mu \mathrm{m}$ long; 6-8.6 (7.4 \pm 1.3$) \mu \mathrm{m}$ wide; SV 13-18.7 (15.8 \pm 2.1$)$ str. in $10 \mu \mathrm{m}$. RV unknown.

Remarks on SV processes and RV: The RV is unknown, so, its ascription to Cocconeis remains doubtful. Nevertheless this taxon differs from Delphineis G.W.AnDREws. The processes are present in each stria. Distribution: Up to now this taxon was only found in Rodrigues Island.

Sub-group $2 B$ ornamentation exclusively on the sternum (cupules, vestigial raphe, low structures at the end of the virgae)

Cocconeis cupulifera RiauX-Gobin et al. (Fig. 14 ) (RIAUX-Gobin et al. 2011b, p. 24, pls 37-38).

Features (Reunion, Rodrigues, Tahiti Islands) SEM. $\mathrm{n}=11 ; 6.3-8.1(6.8 \pm 1) \mu \mathrm{m}$ long; 4-5.3 (4.5 + 0.5) $\mu \mathrm{m}$ wide; SV $15-19(16.7 \pm 1.5)$ str. in $10 \mu \mathrm{m}$; RV $37.5 \mathrm{str}$. in $10 \mu \mathrm{m}$ in mid-valve, 69 in margin.

Remarks on SV processes and RV: The processes are present in each stria, far from the distal areola of each stria, and not in a groove. The RV has a denser marginal striation (composed of macroareolae) than on the rest of the valve (round areolae). Some specimens from Rodrigues do not show cupules.

Note: Cocconeis cupulifera has some similarity with C. paucistriata (see below), but the latter has short striae in mid-valve and no volate SV hymenes.
Distribution: Reunion, Rodrigues and Tahiti Islands.

Cocconeis hauniensis WITKOWSKI emend. WITKOWSKI (Fig. 15)

(WitкоWsкi 1993, Wiткоwski et al. 2000, pl. 42, figs 1-7, pl. 55, fig. 1; RiauX-Gobin \& Romero 2003, pls 41, 42; RiauX-Gobin et al. 2011a, figs 46-49).

Features (Kerguelen specimens, in RIAUX-GoBIN et al. 2011a) SEM: 5.6-16 $\mu \mathrm{m}$ long; 3.5-7 $\mu \mathrm{m}$ wide; SV $17.4-24$ str. in $10 \mu \mathrm{m}$; 30-35 areolae in $10 \mu \mathrm{m}$; RV $17.4-21 ; 30-34.8$ areolae in $10 \mu \mathrm{m}$.

Remarks on SV processes and RV: The RV is not densely striated and shows a marginal row of transapically elongate areolae two times denser than the striae. The SVVC has short fimbriae (Fig. 18). The processes, present in each stria, open externally by tiny pores locating on a low SV marginal groove (RIAUX-GobIN et al. 2011a, figs 47, 49 arrows) and are internally closed by domed structures (RiauX-GoBin et al. 2011a, fig. 46 white arrows, Fig. 18, arrows).

Distribution: This taxon is rarely mentioned in floras. Described from Gulf of Gdansk (WiTKOwsKi et al. 2000), also found in Portugal (RIBEIRo et al. 2013) and Austral Islands (Riaux-Gobin \& Romero 2003).

Cocconeis inequalistriata RIAUX-GoBIN et al. (Fig. 13 ) (RiauX-Gobin et al. 2011b, pl. 48, figs 1-6).

Features (Rodrigues specimens) SEM: n=17; (corrected measurements) $6.3-10.4(8.7 \pm 1.2) \mu \mathrm{m}$ long; 4.2-6.2 (5.3 \pm 0.7$) \mu \mathrm{m}$ wide; SV 21-30 (25 \pm 3$)$ str. in $10 \mu \mathrm{m} ; 45-55 \mathrm{SV}$ areolae in $10 \mu \mathrm{m}$. RV 25 (62 on the margin) str. in $10 \mu \mathrm{m}$.

Remarks on SV processes and RV: The processes are present on the SV mantle, in small marginal depressions, and are irregularly present, on average one per two striae (op. cit., pl. 48, fig. 3).

Distribution: Up to now only found in Rodrigues (absent from the South Pacific, Reunion and Scattered Islands).

Group 3 SV striae very short, marginal and regular (composed of a few minute areolae), raised and radiate structures on the sternum and on the virgae, giving the appearance of a partition of the striae

Cocconeis sp. 2 (Fig. 11 )

(as Cocconeis aff. sovereignii Hustedt in RiauX-Gobin et al. 2011b, pl. 71, figs 1-6, pl. 72, figs 1-4).

Features (Rodrigues specimens, as Cocconeis aff. sovereignii in RIAUX-GoBIn et al. 2011b) SEM: 10.9$15.6(13.5 \pm 1.9) \mu \mathrm{m}$ long; 6.3-11.1 (8.9 \pm 1.8$) \mu \mathrm{m}$ wide; SV 24.4-29.3 (25.8 \pm 2.2$)$ str. in $10 \mu \mathrm{m}$. The proposed RV (ref. cit. pl. 72, figs 1-4) is close to that of C. pseudograta.

Remarks on SV processes and RV: This taxon has 

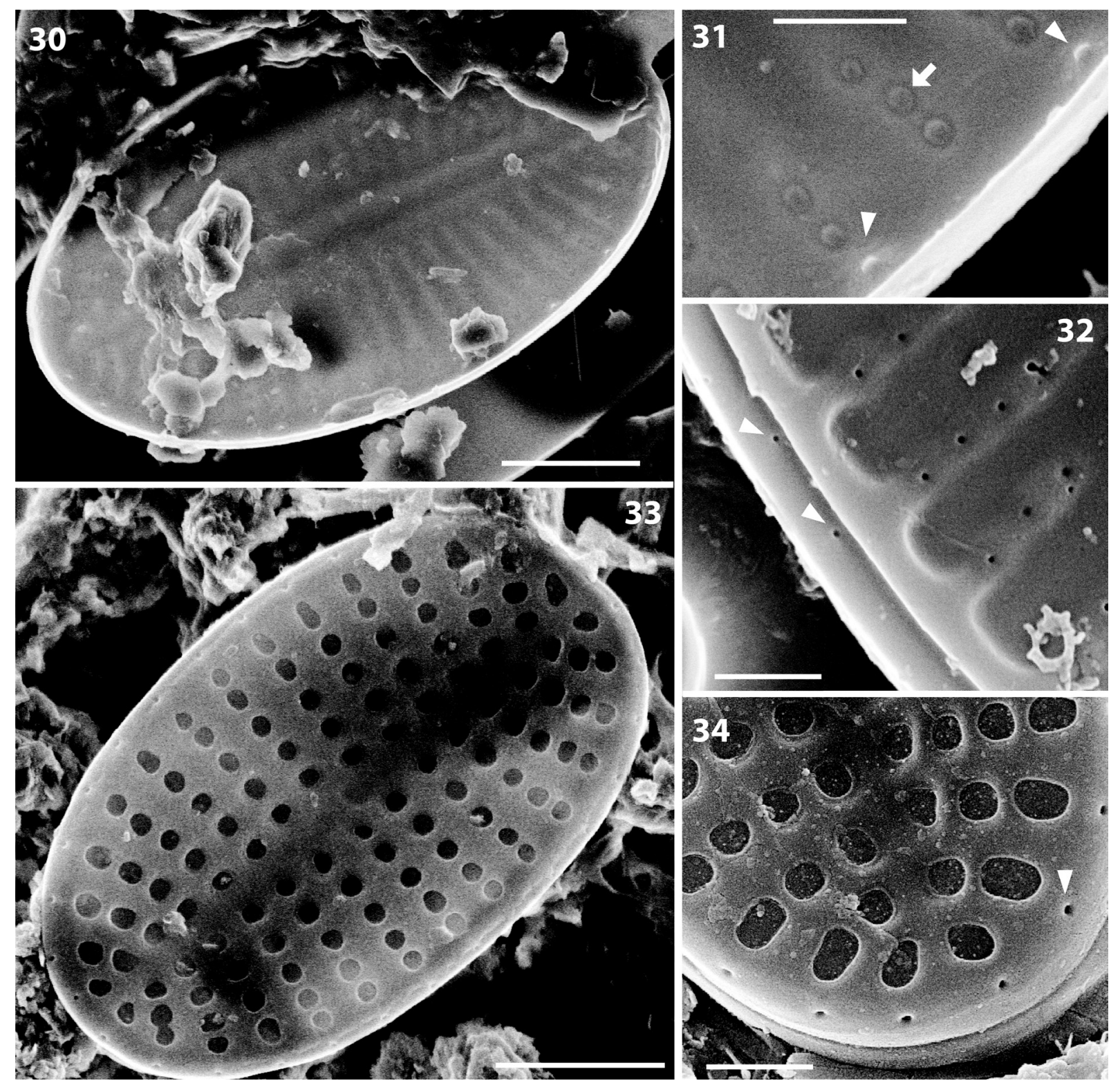

Figs 30-34. SEM: (30-32) C. sp. 4, (30, 31) SV internal view of $C$. sp. 4, with small and domed processes (arrow-heads) and areola hymenes (arrow); (32) external view of $C$. sp. 4 , with minuscule process pores (arrow-heads); $(33,34)$ ?C. sp.6, external view of ?C. sp.6, with marginal pores (arrow-head). Scales bars $2 \mu \mathrm{m}$ (Figs 30, 33); $0.8 \mu \mathrm{m}$ (Fig. 34); $0.5 \mu \mathrm{m}$ (Fig. 31); $0.4 \mu \mathrm{m}$ (Fig. 32).

a low marginal groove but no crista marginalis. The SV processes, irregularly arranged (one lacking every three SV striae), open externally by tiny pores locating in a low groove on the mantle. Internal structure of the processes not observed.

Note: This taxon may be close to $C$. sovereignii, but with denser SV striae and a partition of the SV ornamentation less well-marked than in the type (HustedT 1955, pl. 5, fig. 7; SimONSEN 1987, pl. 607, figs 1-10). The SV of a taxon relatively similar to ours, but with a lower stria density, is illustrated as $C$. sovereignii in Majewska et al. (2014, fig. 30). Cocconeis sp. 2 has also some similarity with but with higher SV stria density. See also Cocconeis cincta pl. 190, fig 38 in ScHMIDT et al. (1874-1959).

Distribution: Only present as rare on Rodrigues Island (absent from the South Pacific, Reunion and Scattered Islands).

\section{Cocconeis sp. 4 (Fig. 12)}

(as (?)Cocconeis sp.1 in RiauX-Gobin et al. 2011b, p. 41, pl. 85, figs $1-4)$ is up to now undefined.

Features (Rodrigues, Reunion, Juan de Nova and Nosy Be Islands specimens) SEM: $\mathrm{n}=9$; 8.7-12.4 (10.7 $\pm 1) \mu \mathrm{m}$ long; $6.2-7.6(7 \pm 0.6) \mu \mathrm{m}$ wide; SV 16.6-24 $(20.3 \pm 2.3)$ str. in $10 \mu \mathrm{m}$.

Remarks on SV processes and RV: The processes open externally by tiny (imperceptible) holes in the groove running around the crista marginalis (Fig. 32, arrow-heads). An internal view of the SV (Fig. 30, specimen from Nosy Be) shows the convex areola hy- 
menes (Fig. 31, arrow) and the domed processes (of smaller diameter than the areola hymenes, but more acute/sharp, Fig. 31 arrowheads). The processes are slightly shifted from the stria alignment, and not regularly located (around 6 processes per 10 striae). The RV remains to be examined.

Distribution: Present in Rodrigues, Reunion, Juan de Nova and Nosy Be Islands, up to now not found in the South Pacific.

\section{Group 4 SV striae composed of coarse areolae, without partition, $R V$ unknown}

\section{Cocconeis sp. 3 (Fig. 17)}

(as Cocconeis sp. [aff. C. guttata Hustedt \& Aleem] in Riaux-GobiN \& ROMERo 2003 , figs $85-86$, pl. 56, figs $1,3,7$ ) is up to now undefined and different from Cocconeis guttata (see Hustedt \& AleEm 1951, fig 1E-F; Simonsen1987, fig. 552, 1-5; RiauX-Gobin et al. 2011b, pls 46, 47).

Features (Kerguelen specimens, RiauX-Gobin \& RoMERO 2003, p. 37, pl. 56, figs 85-86). SEM: $8-11 \mu \mathrm{m}$ long; 4-6.6 $\mu \mathrm{m}$ wide; SV 15-16(18) str. in $10 \mu \mathrm{m} .20$ areolae in $10 \mu \mathrm{m}$. RV not observed.

Remarks on SV processes and RV: The SV areolae are closed by unique circled hymenes located below the valve face. The marginal hyaline and large SV rim shows a row of tiny pores in each stria. The RV remains to be examined.

Distribution: Up to now only found in the Kerguelen Islands.

\section{(?)Cocconeis sp. 6. (Fig. 16)}

Features (Rodrigues Island specimens) SEM. $n=5$; 8.1-8.8 (8.5 \pm 0.3$) \mu \mathrm{m}$ long; 4.8-5.1 (74.9 \pm 0.13$) \mu \mathrm{m}$ wide; SV 16-19 (17.2 \pm 1.4$)$ str. in $10 \mu \mathrm{m}$.

Description: Small-celled taxon, valve face flat, elliptical with more or less flattened apices (Fig. 33). Striae radiate, composed of round to sub-quadrangular axially arranged areolae (hymenes with no apparent slits). Straight to slightly elliptic sternum. Hyaline margin with a groove (but not always) where crater-like (funnel-like) pores are located (Fig. 34), one in the alignment of each stria. High cingulum.

Remarks: The RV is unknown, hence the ascription of (?)Cocconeis sp. 6 to Cocconeis remains doubtful. Nevertheless, this taxon lacks an apical pore field, apical solitary pores or an apical rimoportula aperture, so, its ascription to Achnanthales cannot be excluded.

Distribution: Present in Rodrigues, Moorea and Tahiti Islands.

\section{DISCUSSION}

Location, morphology, origin of the processes Only the SEM permits the observation of the discussed processes that were neglected in the past. A great diversity is linked to these micro-structures and their arrangement (see below). Nevertheless, all the discussed taxa have a straight SV sternum, never sigmoid, and their RV striae, when observed, are radiate and often dense.

The external row of SV pores are located, e.g., 1) in a marginal groove more or less regular and deep, 2) in small marginal depressions, 3) in a deep furrow delimited by the crista marginalis and the border of the mantle, or 4) on the margin of the SV without being associated with a particular structure. These pores have generally the same number as the striae, never more, but sometimes less and irregularly arranged (e.g., a process is not systematically present in each stria, Table 2).

The external pores are never closed and vary from a tiny simple pore to a coarse pore with raised edges. The pores may be difficult to distinguish from areolae when the latter are small, but the row of processes is generally well apart from the distal stria areolae.

In internal view, the processes are generally domed, with features (e.g., diameter, structure, elevation) different from that of the areolae. We have to be cautious about eroded valves that may show apparently open internal processes, while originally obliterated before being eroded due to sample treatment or decay of the cell. Nevertheless, in some species (e.g., Cocconeis sigillata) the internal structure is clearly open on all specimens observed, with a curb of a well structure (while the hymenes of adjacent areolae are intact, cf. Fig. 20). In most species, the internal structure is closed by a domed velum or by a star-like plug (Table 2 ). The structure of the processes is a priori not a reliable criterion permitting the differentiation of groups of taxa: e.g., in some specimens of C. peltoides coarse and open internal processes have been observed while other specimens possess star-like plugs (Fig. 21).

The SVVC, when observed, shows more or less large fimbriae, located between each process (as in $C$. peltoides, Fig. 21). When the marginal striation is irregular (marginal supplementary short stria in Fig. 39), the SVVC fits the arrangement of the processes (Fig. 39 framed arrows for the fimbriae, arrow-heads for the processes). When a process is lacking, the SVVC has no fimbria (as illustrated in C. hauniensis, Fig. 18, framed arrow). As consequence, the SVVC and the simple processes seem to be associated structures. Cultures will help to demonstrate if the latter structures are, or not, built at the same time of the ontogeny. Likewise, the possible role of processes in the connection of the valvocopula to the valve cannot be proved.

The morphological origin of the processes (as possible modified areolae or archaic structures) is unclear. We observe that these simple processes are not present in all Cocconeis taxa but only in a few, among which some similarities can be found (e.g., in the ' $C$. peltoides group'). On the other hand, large differences 

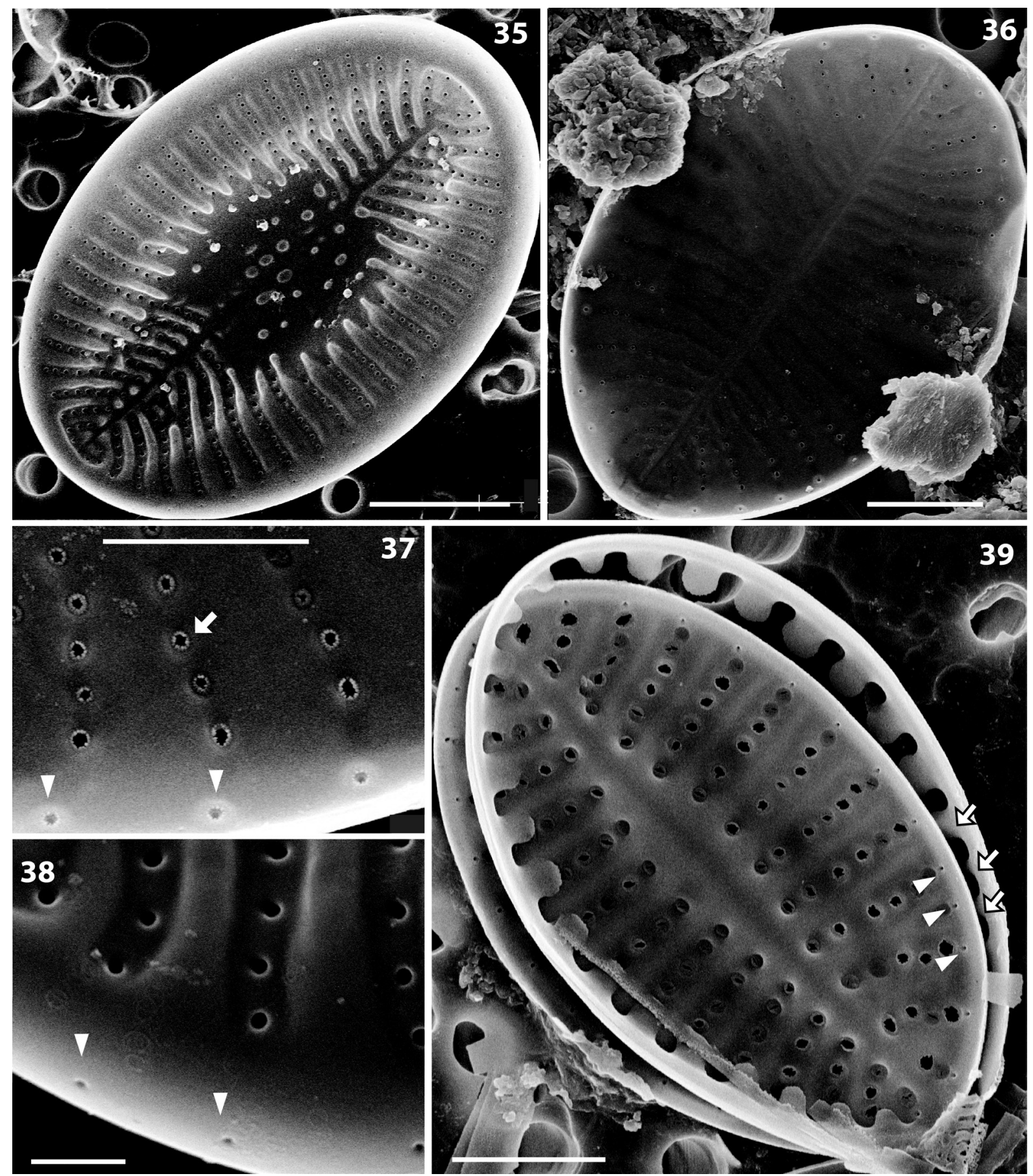

Figs 35-39. (SEM): (35-38) ?C. sp. 7, $(35,38) \mathrm{SV}$ external views of ?C. sp. 7, with the marginal row of small process pores (arrow-heads), $(36,37)$ SV internal views of ?C. sp. 7 , with - probably eroded- processes slightly shifted from the striae and with a domed basis (arrow-heads) and irregular areolae (arrow); (39) C. peltoides, SV internal view of C. peltoides with SVVC fimbriae (framed arrows) fitting the processes (arrow-heads). Scales bars $3 \mu \mathrm{m}$ (Fig. 35); $2 \mu \mathrm{m}$ (Figs 36, 39); $1 \mu \mathrm{m}$ (Fig. 37); $0.4 \mu \mathrm{m}$ (Fig. 38).

exist within several other taxa (see Figs 1-17). Similarly, the role of these processes, e.g., on the physiology of the mature frustule, is questioned (see all hypotheses concerning the role of rimoportulae in Round et al. 1990). During this study, the samples have only been rinsed with distilled water before being mounted on the SEM stub, but we never observed a thread of mucilage extruded through these processes, while, e.g., in several Olifantiella specimens such extruded products are currently observed (RIAUX-Gobin \& AL-HandaL 2012).

Other potentially related taxa and biogeography

The present recollection is probably a minor part of the existing taxa showing a row of processes on their SV, among others, e.g., several Cocconeis with a SV stria partition, such as Cocconeis pelta A.Schmidt, Cocconeis latecostata Hustedt and Cocconeis fluminensis 
(Grunow) H.Peragallo \& M.Peragallo, remain to be observed in the SEM.

The distribution of the observed taxa is diverse, from cosmopolitan (such as Cocconeis peltoides, $C$. hauniensis) to tropical ubiquitous (C. cupulifera, $C$. peltoides var. archaeana, $C$. pseudograta, $C$. sigillata, C. sp. 6 ), austral (C. germainii, C. sp. 1, C. sp. 3), or very local and, up to now, restricted to one island or archipelago (C. inequalistriata, $C$. juandenovensis, C. sp. 2, C. sp. 5, C. sp. 7), or restricted to an oceanic sector (C. sp. 4).

We can note that morphological taxonomic studies concerning marine tropical sites are still scarce, so that numerous new taxa and new structures, will probably be discovered in the next decades. Further high resolution SEM investigations will help. On the other hand, the recent progress in genetics (THERIOT et al. 2010, and refs therein; NAKov 2014; Witkowski, Li \& DĄBEK, unpublished observations) will permit the building of genetic trees and confirm or refute the affiliation of taxa, particularly concerning Cocconeis and related taxa, showing particular morphological structures.

\section{ACKNOWLEDGEMENTS}

We acknowledge Dimitri Gorand (C2M, Perpignan University, France) for his assistance with the SEM, Jean-Pierre Pointier and Peter Esteve (USR 3278) for their help with the iconography, and Luc Ector for bibliographic help. Thanks are due to anonymous reviewers for their constructive remarks and to the CRIOBE-Moorea team for valuable help in the field. CNRS-USR 3278 funded diatom studies in the French Polynesia and to Schweizerbart (www. schweizerbart.de) for giving permission to reproduce a figure from Bibliotheca Diatomologica 57. We also acknowledge Terres Australes et Antarctiques Françaises (TAAF) who permitted the participation in the Kerguelen and Scattered Islands campaigns and the Polish National Science Centre (NCN) in Cracow grant $n^{\circ}$ N2012/04/A/ ST10/00544 for supporting the Nosy Be Island campaign.

\section{REFERENCES}

AnONymous (1975): Proposals for a standardization of diatom terminology and diagnoses. - Nova Hedwigia, Beih. 53: 323-354.

Hasle, G.R. (1972): Two types of valve processes in centric diatoms. - Nova Hedwigia, Beih. 39: 55-78.

Hustedt, F. (1931-1959): Die Kieselalgen Deutschlands, Österreichs und der Schweiz unter Berücksichtigung der übrigen Länder Europas sowie der angrenzenden Meeresgebiete. -In: Rabenhorst, L. (ed): 2. Teil. Kryptogamen-Flora von Deutschland, Österreich und der Schweiz. Band 7, Teil 2. - 845 pp., Akademische Verlagsesellschaft, Leipzig.

Hustedt, F. (1939): Die Diatomeenflora des Küstengebietes der Nordsee vom Dollart bis zur Elbemündung. I. Die Diatomeenflora in den Sedimenten der unteren Ems sowie auf den Watten in der Leybucht, des Memmert und bei der Insel Juist. - Abh. Natwiss. Ver Brem. 31: 571-677.

Hustedt, F. (1955): Marine littoral diatoms from Beaufort, North Carolina. - Bulletin - Duke University Marine Station 6: 1-67.
Hustedt, F. \& Aleem, A.A. (1951): Littoral diatoms from the Salstone near Plymouth. - J. Mar. Biol. Assoc. U. K. 30: 177-196.

Lange-Bertalot, H. (1997): Frankophila, Mayamaea und Fistulifera: drei neue Gattungen der Klasse Bacillariophyceae. - Arch. Protistenkunde 148: 65-76.

Majewska, R.; D’Alelio, D. \& De Stefano, M. (2014): Cocconeis Ehrenberg (Bacillariophyta), a genus dominating diatom communities associated with Posidonia oceanica Delile (monocotyledons) in the Mediterrranean Sea. - Aquat. Bot. 112: 48-56.

Montgomery, R.T. (1978): Environmental and ecological studies of the diatom communities associated with the coral reefs of the Florida Keys, vols I \& II. - Unpublished Ph.D. thesis, Florida State University, Tallahassee, FL. 760 pp.

NAKov, T. (2014): Studies of phylogenetic relationships and evolution of functional traits in diatoms [PhD. thesis]. - The University of Texas at Austin, $135 \mathrm{pp}$.

Peragallo, H. \& Peragallo, M. (1907-1908): Diatomées marines de France et des districts maritimes voisins. - M.J. Tempère, Grez-sur-Loing, 492 pp., 137 Pl.

Riaux-Gobin, C. \& Al-Handal, A.Y. (2012): New species in the marine diatom genus Olifantiella (Bacillariophyta, Biraphidineae) from Rodrigues Island (Western Indian Ocean). - Fottea 12: 199-217.

Riaux-Gobin, C. \& Compère, P. (2009): Olifantiella mascarenica gen. \& sp. nov., a new genus of pennate diatom from Réunion Island, exhibiting a remarkable internal process. - Phycol. Res. 57: 178-185.

Riaux-Gobin, C.; Compère, P. \& Al-Handal, A.Y. (2011a): Species of the Cocconeis peltoides group with a marginal row of unusual processes (Mascarenes and Kerguelen Islands, Indian Ocean). - Diatom Res. 26: 325-338.

Riaux-Gobin, C. \& Romero, O. (2003): Marine Cocconeis Ehrenberg (Bacillariophyceae) species and related taxa from Kerguelen's Land (Austral Ocean, Indian sector). - Bibl. Diatomol. 47: 1-189.

RiauX-Gobin, C.; Romero, O.E. \& Al-HandaL, A.Y. (2009): Cocconeis costata var. subantarctica var. nov., a new diatom (Bacillariophyta) off Kerguelen Archipelago (Southern Ocean). - Diatom Res. 24: 393-404.

Riaux-Gobin, C.; Romero, O.E.; Compère, P. \& Al-Handal, A.Y. (2011b): Small-sized Achnanthales (Bacillariophyta) from coral sands off Mascarenes (Western Indian Ocean). - Bibl. Diatomol. 57: 1-234.

Riaux-Gobin, C.; Witkowski, A. \& Romero, O.E. (2007): Cocconeis germainii sp. nov. (Bacillariophyceae) and a related taxon from Kerguelen Archipelago (Austral Ocean, Indian Sector). - Diatom Res. 22: 329-340.

Ribeiro, L.; Brotas, V.; Brotas, V.; Rincé,Y. \& Jesus, B. (2013): Structure and diversity of intertidal benthic diatom assemblages in contrasting shores: a case study from the Tagus estuary. - J. Phycol. 49: 258270 .

Romero, O.E. \& Riaux-Gobin, C. (2014): Two closely-related species of Cocconeis (Bacillariophyta): comparative study and typification. - Special issue of Plecevo. 147: 426-438. http://dx.doi.org/10.5091/ plecevo.2014.996

Ross, R. \& Sims, P.A. (1972): The fine structure of the frustule in centric diatoms: A suggested terminology. Brit. Phycol. J. 7: 139-163. 
Ross R.; Cox E.J.; Karayeva, N.I.; ManN, D.G.; Paddock, T.B.B.; Simonsen, R. \& Sims, P.A. (1979): An amended terminology for the siliceous components of the diatom cell. - Nova Hedwigia, Beih. 64: 513-533.

Round, F.E.; Crawford, R.M. \& Mann, D.G. (1990): The diatoms. Biology and morphology of the genera. 747 pp., Cambridge University Press, Cambridge.

Sar, E.A.; Romero, O.E. \& Sunesen, I. (2003): Cocconeis Ehrenberg and Psammococconeis Garcia (Bacillariophyta) from the Gulf of San Matías, Patagonia, Argentina. - Diatom Res. 18: 79-106.

Schmidt, A. et al. (1874-1959): Atlas der Diatomaceenkunde. Heft 1-120, Tafeln 1-480. - Aschersleben, Leipzig.

Simonsen, R. (1987): Atlas and Catalogue of the diatom types of Friedrich Hustedt. - J. Cramer Berlin/Stuttgart. Vol. 1: Catalogue. pp. 1-525, Vol. 2: Atlas, Pl. 1-395, Vol. 3: Atlas, Pl. 396-772.

SundBäck, K. \& SNOEIJS, P. (1991): Effects of nutrient enrichment on microalgal community composition in a coastal shallow-water sediment system: an experimental study. - Bot. Mar. 34: 341-358.

Theriot, E.C.; Ashworth, M.; Ruck, E.; Nakov, T. \& JanSEN, R.K. (2010): A preliminary multigene phylogeny of the diatoms (Bacillariophyta): challenges for future research. - Plecevo FastTrack: 278-296. Doi: 10.5091/plecevo.2010.418.
Van De Vijver, B.; Frenot, Y.; Beyens, L. \& Lange-BerTALOt, H. (2005): Labellicula, a new diatom genus (Bacillariophyta) from Île de la Possession (Crozet Archipelago, Subantarctica). - Cryptogamie Algol. 26: $125-133$.

Vyverman, W.; Sabbe, K.; Mann, D.G.; Kilroy, C.; Vyverman, R.; Vanhoutte, K. \& Hodgson, D. (1998): Eunophora gen. nov. (Bacillariophyta) from Tasmania and New Zealand: description and comparison with Eunotia and amphoroid diatoms. - Eur. J. Phycol. 33: 95-111.

WitKowski, A. (1993): Cocconeis hauniensis sp. nov., a new epipsammic diatom from Puck Bay, Poland. - Nord. J. Bot. 13(4): 467-471.

Witkowski, A.; Lange-Bertalot, H. \& Metzeltin, D. (2000): Diatom flora of marine coasts I. - Iconogr. Diatomol. 7: 1-925.

C) Czech Phycological Society (2015)

Received November 25, 2014

Accepted April 3, 2015 